\title{
Reference ranges for plasma creatinine during the first month of life
}

\author{
P T RUDD, E A HUGHES, M M PLACZEK, AND D T HODES \\ Department of Paediatrics and Neonatal Medicine, Institute of Child Health, Hammersmith Hospital, \\ London; Department of Paediatrics, Hillingdon Hospital, Uxbridge, Middlesex
}

SUMMARY A reference range of plasma creatinine levels for the first month of life derived from 238 babies of 25-42 weeks' gestation is presented. Measurements were performed on a Beckman Creatinine Analyser 2, which uses the Jaffé rate reaction method. There was a decline in plasma creatinine level with increasing postnatal and gestational age. Infants undergoing mechanical ventilation at age 2 days had a significantly increased creatinine level.

With increasing resources being devoted to the care of the preterm infant there is a need for a reference range for plasma creatinine levels in the neonatal period so that renal failure can be identified and treated promptly. True creatinine is inversely proportional to the glomerular filtration rate corrected for body length. ${ }^{1}$ Previous studies have shown that there is a 2-fold rise in glomerular filtration rate in the first 14 days of life $^{2}$ and that glomerular filtration rate is proportional to gestational age. ${ }^{3}$ Thus it is to be expected that there will be a wide variation in plasma creatinine levels in newborn infants. Stonestreet and $\mathrm{Oh}^{4}$ measured plasma creatinine concentrations in 57 low birthweight infants but obtained only 81 values. Feldman and Guignard ${ }^{5}$ measured plasma creatinine in 56 babies, the most immature of whom were of 30 weeks' gestation. Many babies receiving intensive care are less mature than this.

\section{Materials and methods}

Subjects. Samples were taken from 238 babies during an 8-month period. Informed consent was obtained from the parents of these babies, the study having been approved by the hospital ethical committee.

Blood samples $(100 \mu l)$ were obtained by heelprick, venepuncture, or through an umbilical artery catheter at $2,7,14,21$, and 28 days after birth when blood was obtained for routine tests.

Babies from the regional neonatal intensive care unit at Hammersmith Hospital were studied together with those from the subregional intensive care unit at Hillingdon Hospital, babies from the lying-in ward, and infants seen at baby clinics during the first month of life. The weights of the babies according to gestational age are shown in Table 1.
Table 1 Birthweights of the infants studied

\begin{tabular}{lllr}
\hline $\begin{array}{l}\text { Gestation } \\
\text { (weeks) }\end{array}$ & $\begin{array}{l}\text { Number of } \\
\text { babies }\end{array}$ & \multicolumn{2}{c}{ Birthweight $(g)$} \\
\cline { 2 - 4 } & & Mean & Range \\
\hline $25-28$ & 33 & 930 & $660-1300$ \\
$29-32$ & 78 & 1435 & $750-2270$ \\
$33-36$ & 54 & 2015 & $1040-2960$ \\
$37-42$ & 73 & 2900 & $1600-4360$ \\
\hline
\end{tabular}

Gestational age was calculated from the first day of the mother's last menstrual period and a Dubowitz et al. ${ }^{6}$ gestational assessment was performed on all infants in the neonatal intensive care units. If this differed by more than 2 weeks, the most reasonable value was taken using other information-such as antenatal ultrasound findings.

The following were excluded from the study: babies with congenital heart disease, babies in cardiac failure from a patent ductus arteriosus, or those who had received indomethacin during the previous 48 hours, babies who had become oliguric as a result of birth asphyxia, and those with various renal anomalies or muscle disease.

Because the aim was to establish a reference range, certain factors which might influence the plasma creatinine values were considered at 2 and 7 days in each gestational age group as follows: pre-eclamptic toxaemia in the mother; birth asphyxia defined as an Apgar score of 4 or less at one minute or 6 or less at five minutes; severe acidosis with a recorded arterial $\mathrm{pH}$ of $7 \cdot 1$ or less in the first week of life; gentamicin administered at a dose of 2.5-3.0 $\mathrm{mg} / \mathrm{kg}$ per day for babies under $1000 \mathrm{~g}$ and 5-6 $\mathrm{mg} / \mathrm{kg}$ per day for babies over $1000 \mathrm{~g}$; the volume of fluid given on the 2 nd and 7 th days of life; mechanical ventilation at 2 and 7 days. There were 74 infants of 32 weeks or less for whom creatinine values were available at 2 days. Of these, 32 received ventilation 
and 28 of these had idiopathic respiratory distress syndrome.

\section{Biochemical method}

The Beckman Creatinine Analyser $2^{7} 8$ measures the rate of production of the red complex formed when creatinine reacts with alkaline picrate. Plasma $(30 \mu \mathrm{l})$ is needed for a single analysis, of which $25 \mu l$ is introduced into the machine, the reading being made at 25.6 seconds, reducing interference from early and late-reacting chromogens.

Bilirubin was not found to interfere with the creatinine analyses. The study was carried out on pooled baby sera and bilirubin was added to a level of $400 \mu \mathrm{mol} / 1$. Because high levels of plasma pyruvate are present during the lactic acidosis which may occur in babies with severe respiratory distress syndrome, ${ }^{9}$ a pyruvate interference study was performed in which increasing amounts of pyruvate were added to plasma and the effects on creatinine measured. The addition of $0.1 \mathrm{mmol} / 1$ of pyruvate to a plasma sample produced a rise of 5 $\mu \mathrm{mol} / \mathrm{l}$ in the creatinine value.

Using a control serum with plasma creatinine at $53 \mu \mathrm{mol} / 1$ the standard deviation (SD) of 11 measurements was $\pm 3.9 \mu \mathrm{mol} / \mathrm{l}$, with a coefficient of variation $(\mathrm{CV})$ of $6.4 \%$; similarly at a concentration of $128 \mu \mathrm{mol} / 1$ the $\mathrm{SD}$ was $\pm 5.3 \mu \mathrm{mol} / 1$ with a $\mathrm{CV}$ of $4.4 \%$ on 22 measurements. The between-batch variation at a plasma creatinine level of $141 \mu \mathrm{mol} / \mathrm{l}$ on 42 analyses gave an SD of $\pm 3.9 \mu \mathrm{mol} / 1$ and a $\mathrm{CV}$ of $2 \cdot 8 \%$.

\section{Results}

There was a fall in plasma creatinine concentrations both with increasing postnatal and gestational age (Table 2 and Figure). The 2-day values of plasma creatinine are given in three columns in the table,

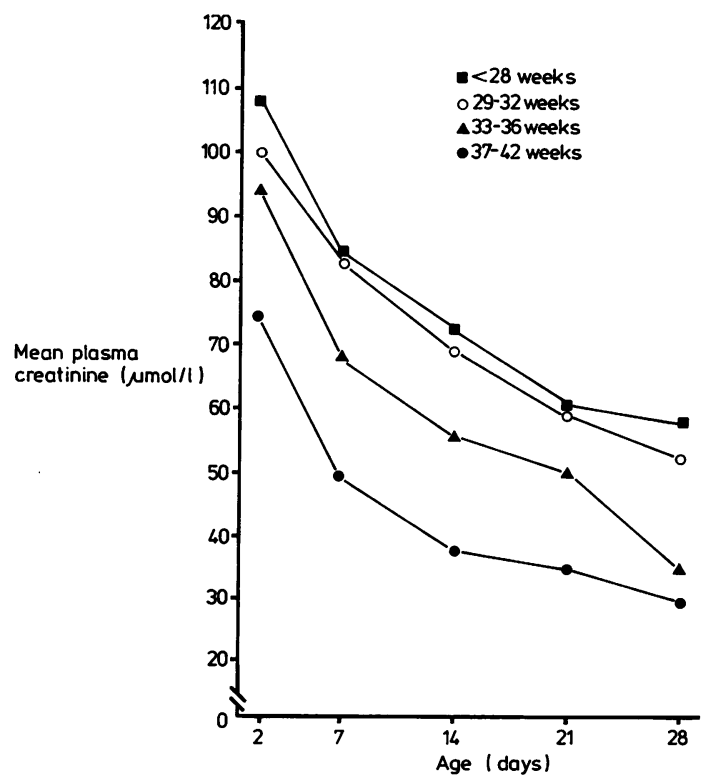

Figure Relationship between mean plasma creatinine levels and postnatal age in the different gestational age groups. Infants undergoing mechanical ventilation at 2 days are excluded.

because of the appreciable difference between plasma creatinine level in babies receiving mechanical ventilation and those breathing spontaneously. When the data were analysed using an unpaired $t$ test only the infants of 29-32 weeks' gestation receiving mechanical ventilation were found to have a significantly increased plasma creatinine level $(P<0.01)$. Similarly, the severely acidotic infants in this gestational age group were found to have a raised creatinine level $(P<0.01)$, but all these babies were also receiving mechanical ventilation.

Table 2 Plasma creatinine values in the first month of life

\begin{tabular}{|c|c|c|c|c|c|c|c|}
\hline \multirow{3}{*}{$\begin{array}{l}\text { Gestation } \\
\text { (weeks) }\end{array}$} & \multicolumn{7}{|c|}{ Postnatal age (days) } \\
\hline & \multirow{2}{*}{$\overrightarrow{2}$} & 2 & 2 & 7 & 14 & 21 & 28 \\
\hline & & $\begin{array}{l}\text { Breathing } \\
\text { spontaneously }\end{array}$ & Ventilated & All babies & & & \\
\hline 28 & $\begin{array}{r}116 \pm 40 \\
(n=24)\end{array}$ & $\begin{array}{r}108 \pm 20 \\
(n=8)\end{array}$ & $\begin{array}{c}121 \pm 45 \\
(n=16)\end{array}$ & $\begin{array}{l}84 \pm 32 \\
(n=22)\end{array}$ & $\begin{array}{l}72 \pm 32 \\
(n=25)\end{array}$ & $\begin{array}{l}60 \pm 33 \\
(\mathrm{n}=25)\end{array}$ & $\begin{array}{l}58 \pm 24 \\
(n=24)\end{array}$ \\
\hline 29-32 & $104 \pm 38$ & $100 \pm 32$ & $115 \pm 43$ & $83 \pm 41$ & $69 \pm 32$ & $59 \pm 32$ & $52 \pm 33$ \\
\hline $33-36$ & $\begin{array}{l}(n=50) \\
93 \pm 39 \\
(n=36)\end{array}$ & $\begin{array}{l}(n=36) \\
94 \pm 39 \\
(n=32)\end{array}$ & $\begin{array}{l}(n=16) \\
87 \pm 46 \\
(n=4)\end{array}$ & $\begin{array}{l}(n=56) \\
68 \pm 44 \\
(n=31)\end{array}$ & $\begin{array}{l}(n=42) \\
55 \pm 36 \\
(n=27)\end{array}$ & $\begin{array}{l}(n=29) \\
50 \pm 37 \\
(n=20)\end{array}$ & $\begin{array}{l}(n=30) \\
35 \pm 24 \\
(n=12)\end{array}$ \\
\hline $37-42$ & $\begin{array}{l}75 \pm 38 \\
(n=27)\end{array}$ & $\begin{array}{l}75 \pm 38 \\
(n=27)\end{array}$ & - & $\begin{array}{l}50 \pm 36 \\
(n=39)\end{array}$ & $\begin{array}{l}38 \pm 20 \\
(n=19)\end{array}$ & $\begin{array}{l}35 \pm 20 \\
(n=19)\end{array}$ & $\begin{array}{l}30 \pm 18 \\
(n=15)\end{array}$ \\
\hline
\end{tabular}

Mean plasma creatinine $\mu \mathrm{mol} / 1 \pm 2 \mathrm{SD}$.

Conversion SI to traditional units: $1 \mu \mathrm{mol} / 1 \approx 0.0113 \mathrm{mg} / 100 \mathrm{ml}$. 
Factors which were thought might influence the plasma creatinine values were also analysed using multiple regression. This enabled us to look at the effect of mechanical ventilation and other factors in all babies at a particular postnatal age. The analysis is able to take into account the fall in creatinine level with increasing gestational age, which is necessary with a larger sample than that included in the unpaired $t$ test. Using this method of analysis mechanical ventilation was associated with an increased plasma creatinine level at 2 days $(P<0.05)$ but severe acidosis did not have a significant effect on the creatinine. Gentamicin administration had no significant effect on creatinine, nor did pre-eclamptic toxaemia, birth asphyxia, or fluid administration.

The following equation relating creatinine to gestational age and postnatal age was derived from the data, in which all babies except those ventilated at 2 days were included:

$\log _{e}$ creatinine $=6 \cdot 400-0.3026 \times \log _{e}$ age in days $-0.4927 \times$ gestation in weeks

From this equation a normal range has been derived (Appendix). While the values derived from the equation correspond closely to the value we obtained in babies 7-28 days of age, the $95 \%$ confidence limits for babies of 2 days are well outside the 2 SD values given in Table 2 .

\section{Discussion}

We have shown a fall in plasma creatinine level with increasing gestational and postnatal age. These values are in accordance with the measurements made of glomerular filtration rate by Guignard et $a l .{ }^{2}$ and Siegel and $\mathrm{Oh}^{3}$ on neonates. There was a significant increase in plasma creatinine level in babies undergoing mechanical ventilation for respiratory distress which corresponds to the finding of Guignard et al. of a reduced glomerular filtration rate in infants with this condition. ${ }^{10}$

Unlike Feldman and Guignard, ${ }^{5}$ who studied the effect of gentamicin on the creatinine level during the first month of life, we were unable to demonstrate a significant effect of this drug. However, our observations were made only in the first week, and it is possible that later observations might have produced different results. There was no correlation between concentration of plasma creatinine and fluid input. While the relationship between fluid input and urea was not examined in this study, it is known that urea values are affected both by the fluid and protein intake, each of which shows considerable variation in the newborn preterm infant.

Although the most accurate measurements of glomerular filtration rate are made by using either radioisotopes or inulin clearance, these methods are not suitable for routine use in the low birthweight baby. Counahan et al. ${ }^{11}$ have shown that measurement of plasma creatinine is a more reliable indicator of glomerular filtration rate than creatinine clearance in children, even if a 24-hour urine collection, difficult to obtain in babies, has been completed. The most accurate measurements of true creatinine are made using high performance liquid chromatography but this method is not widely available.

Several factors make the Beckman method particularly useful for the measurement of creatinine in newborn babies. The amount of plasma required is small $(25 \mu l)$ and results can be obtained quickly. Bilirubin had no effect on the creatinine values in our study and that of Cottrell and Frings. ${ }^{7}$ Furthermore, lipids do not appear to interfere with the methods unless present at a very high plasma concentration. While pyruvate has an effect on the measurement, it decays quickly unless a preservative is added. Ketones interfere with this method but they were not seen in any baby during this study.

Because the values derived from the equation (Appendix) lie well outside the values we obtained for babies at 2 days, it is suggested that the data presented in Table 1 are used as a reference range of plasma creatinine. It is hoped that this information will be used in the identification and treatment of renal failure in the preterm infant.

\section{Appendix}

A range of creatinine derived from the equation given in the results.

Median values of plasma creatinine ( $\mu \mathrm{mol} / \mathrm{l})$ ( $\pm 95 \%$ confidence limits)

\begin{tabular}{llllll}
\hline $\begin{array}{l}\text { Gestation } \\
\text { (weeks) }\end{array}$ & \multicolumn{2}{l}{ Age (days) } & & & \\
& 2 & 7 & 14 & 21 & 28 \\
\hline 28 & 130 & 84 & 68 & 60 & 55 \\
& \pm 90 & \pm 61 & \pm 50 & \pm 44 & \pm 40 \\
30 & 111 & 76 & 62 & 55 & 50 \\
& \pm 81 & \pm 56 & \pm 45 & \pm 40 & \pm 37 \\
32 & 101 & 69 & 56 & 50 & 45 \\
& \pm 74 & \pm 50 & \pm 41 & \pm 36 & \pm 33 \\
34 & 91 & 63 & 51 & 45 & 41 \\
& \pm 67 & \pm 46 & \pm 37 & \pm 33 & \pm 30 \\
36 & 83 & 57 & 46 & 41 & 37 \\
& \pm 60 & \pm 41 & \pm 34 & \pm 30 & \pm 27 \\
38 & 75 & 51 & 42 & 37 & 34 \\
& \pm 55 & \pm 38 & \pm 30 & \pm 27 & \pm 25 \\
40 & 68 & 47 & 38 & 33 & 31 \\
& \pm 50 & \pm 34 & \pm 28 & \pm 24 & \pm 22 \\
\hline
\end{tabular}

We thank Professor T M Barratt for guidance, and Professor M J Healy for statistical advice; 
Dr P A Davies, Dr M Silverman, and Professor I D P Wootton for help; the resident staff and Miss Castle on the Neonatal Unit at Hammersmith Hospital.

\section{References}

1 Schwartz G J, Haycock G B, Edelmann C M, Jr, Spitzer A. A simple estimation of glomerular filtration rate in children derived from body length and plasma creatinine. Pediatrics 1976 ; 58 : 259-63.

2 Guignard J P, Torrado A, Da Cunha O, Gautier E. Glomerular filtration rate in the first three weeks of life. J Pediatr 1975; 87: 268-72.

3 Siegel $\mathbf{S ~ R , ~ O h ~ W . ~ R e n a l ~ f u n c t i o n ~ a s ~ a ~ m a r k e r ~ o f ~ h u m a n ~}$ fetal maturation. Acta Paediatr Scand 1976; 65: 481-5.

4 Stonestreet B S, Oh W. Plasma creatinine levels in low birth-weight infants during the first three months of life. Pediatrics 1978; 61: 788-9.

5 Feldman H, Guignard J P. Plasma creatinine in the first month of life. Arch Dis Child 1982; 57: 123-6.

${ }^{6}$ Dubowitz L M S, Dubowitz V, Goldberg C. Clinical assessment of gestational age in the newborn infant. J Pediatr 1970; 77: 1-10.

7 Cottrell D B, Frings C S. Evaluation of the Beckman Creatinine Analyser 2. Clin Biochem 1979; 12: 159-61.

8 Hicks J M, Iosefsohn M, Lewis S A. Evaluation of the Beckman Creatinine Analyser. Clin Chem 1979; 25: 1005-8.

9 Beca J P, Scopes J W. Serial determinations of blood lactate in respiratory distress syndrome. Arch Dis Child $1972 ; 47: 550-7$.

10 Guignard J P, Torrado A, Mazouni S M, Gautier E. Renal function in respiratory distress syndrome. $J$ Pediatr 1976; 88: 845-50.

11 Counahan R, Chantler C, Ghazali S, Kirkwood B, Rose F, Barratt T M. Estimation of glomerular filtration rate from plasma creatinine concentration in children. Arch Dis Child 1976; 51: 875-8.

Correspondence to Dr P T Rudd, Department of Paediatrics and Neonatal Medicine, Hammersmith Hospital, Du Cane Road, London W12 0HS.

Received 22 October 1982

\section{Referees 1982}

We continue to depend heavily on the help we get from our referees who assess and, in many cases, suggest significant improvements to the papers. This is the only opportunity we have to acknowledge publicly the work done by them during the past year.

D P Addy

E Alberman

D G Altman

B M Ansell

A Aperia

G C Arneil

F N Bamford

P R H Barbor

D Barltrop

N D Barnes

T M Barratt

A J Barson

J D Baum

P F Benson

A Bentovim

J G Bissenden

B D Bower

R D H Boyd

J T Brocklebank

C G D Brook

O G Brooke

M F G Buchanan

J M H Buckler

N A J Carson

F Carswell

D N Challacombe

T L Chambers
C Chantler

J M Chessells

M L Chiswick

G S Clayden

B E Clayton

J B Clegg

R W I Cooke

T J David

D P Davies

P A Davies

J A Davis

$P$ Dear

R Dickson

M Dillon

J A Dodge

S W D'Souza

V Dubovitz

P M Dunn

G J Ebrahim

D F Egan

J L Emery

$S$ Evans

J W Farquhar

H R Gamsu

D Gardner-Medwin

J Garrow

A M Geddes
R H George

J F T Glasgow

P J Graham

D B Grant

S H Green

P Hambling

R B Harcourt

R A Harkness

D Hatch

G B Haycock

M J R Healy

J Z Heckmatt

K S Holt

I B Houston

E R Howard

D Hull

A S Hunter

C M Illingworth

R S Illingworth

A Jacobs

D I Johnson

R S Jones

B E Kendall

H P Lambert

J V Leonard

M I Levene

R Levinsky 
John Forfar, we are proud to award you the 1983 James Spence Medal, the British Paediatric Association's highest honour, for your outstanding contributions to the advancement of paediatrics.

\section{James Spence Medallists}

1960 Professor A A Moncrieff

1961 Professor R A McCance

1963 Sir F Macfarlane Burnet

1964 Professor L S Penrose

1965 Dr Cicely D Williams

1967 Professor R R A Coombs
1968 Dr Mary D Sheridan

Dr D W Winnicott

1969 Dr G S Dawes

1970 Professor D V Hubble

1971 Dr W W Payne

1972 Dr R C Mac Keith

1973 Professor C A Clarke

1974 Dr J Bowlby

1976 Dr D M T Gairdner

1977 Professor R S Illingworth

1978 Dr S D M Court

1979 Professor K W Cross

1980 Professor J M Tanner

1981 Dr Elsie M Widdowson

1982 Dr D MacCarthy

\section{Erratum}

Reference range of plasma creatinine in the newborn infant in the first month of life. Arch Dis Child 1983; 58: $212-5$.

The equation printed on page 214 is incorrect and should read:

$\log$ e creatinine $=6.400-0.3026 \times \log \mathrm{e}$ age in days $-0.04927 \times$ gestation in weeks.

The authors P T Rudd, E A Hughes, M M Placzek, and D T Hodes apologise for their error. 